\title{
Toll-like receptor 2 mediates deposition of collagen I in adipose tissue of high fat diet-induced obese mice
}

\author{
BING SONG ${ }^{*}$, HAOQIANG ZHANG ${ }^{*}$ and SUPING ZHANG \\ Endocrinology Department, First Affiliated Hospital of Jinzhou Medical University, Jinzhou, Liaoning 121000, P.R. China
}

Received March 4, 2017; Accepted November 23, 2017

DOI: $10.3892 / \mathrm{mmr} .2018 .8590$

\begin{abstract}
Obesity is marked by deposition of collagen I in adipose tissue. Toll like receptor (TLR) 2 is involved in lipid metabolism, however the association between TLR2 and collagen I remains unclear. The present study was designed to investigate the effect of TLR2 knockout on collagen I in adipose tissue in obese mice. TLR2 knockout and C57BL/6J mice (aged 4 weeks) were fed normal chow or a high-fat-diet for 16 weeks. Compared with adipose tissue from lean controls, that from C57BL/6J mice fed a high-fat diet had increased levels of collagen I, TIMP1 and TGF $\beta 1$ and lower levels of MMP1. However, adipose tissue from TLR2 knockout mice fed a high-fat diet revealed decreased levels of collagen I, TIMP metallopeptidase inhibitor (TIMP)1, and transforming growth factor (TGF) $\beta 1$, in addition to increased levels of matrix metallopeptidase (MMP)1. These findings suggest that, in the adipose tissue of obese mice, TLR2 is involved in the metabolism of collagen I and may exhibit a role in the metabolism of MMP1, TIMP1 and TGF $\beta 1$.
\end{abstract}

\section{Introduction}

The rates of overweight and obesity have increased over recent decades (1-3) with the incidences of pre-diabetes and diabetes $(4,5)$. Obesity is characterized by hyperlipidemia, proliferation and hypertrophy in adipocytes with the deposition of collagen I in adipose tissue (6-9). Deposition of collagen I in adipose tissue is associated with insulin sensitivity (10). Previous reports have demonstrated an inverse correlation between adipocyte size and collagen I deposition, which is a

Correspondence to: Dr Bing Song, Endocrinology Department, First Affiliated Hospital of Jinzhou Medical University, 3-40 Songpo Street, Jinzhou, Liaoning 121000, P.R. China

E-mail: 1131780275@qq.com

*Contributed equally

Key words: obesity, collagen I, Toll-like receptor 2, inflammation factors, Matrix metalloproteinase 1, Tissue inhibitor of metalloproteinase 1 hallmark of fibrosis (11-13). These findings suggest a role for fibrosis in negatively regulating adipocyte hypertrophy.

Over-expression of collagen I adipose tissue in obesity has been well studied; however, the effect of TLR2 on collagen I remains unclear. TLR2, along with TLR1 and TLR6, recognizes a wide variety of pathogen-associated molecules including lipoproteins, peptidoglycans, lipophilic acids, zymosan, mannan, and free fatty acid (FFA) (14). Plasma FFA could activate TLR2 (15) and downstream inflammatory factors, which regulate MMPs and TIMPs (8). MMPs and TIMPs regulate the deposition of collagen I, which is one of the most important components of the extracellular matrix (ECM) $(16,17)$. ECM levels in adipose tissue are also increased in human and murine obesity $(10,13,18,19)$. In the pesent study, the role of TLR2 in the deposition of collagen I in adipose tissue was explored in TLR2 gene knockout mice fed a high-fat diet.

\section{Materials and methods}

Animals and groups. Male C57BL/6J mice [SCXK (Jing) 2009-0015] and age-matched TLR2 gene knockout mice (022507) were purchased from HFK (Beijing HFK Bioscience Co., Ltd., Beijing, China) and Jackson Laboratory (Bar Harbor, ME, USA), respectively. Mice were divided in 4 groups: Normal control mice (C57BL/6J) fed common chow (NC), TLR2 knockout mice fed common chow (TK), C57BL/6J mice fed a high-fat (60\%) diet to model obesity (OB), and TLR2 knockout mice fed a high-fat diet to model obesity (TO). To monitor weight gain, mice were weighed every 2 weeks, especially the following 3 important time points. Prior to the start of the experiment ( 4 weeks of age), after the 4 th week of the experiment ( 8 weeks of age) and at the end of the experiment (20 weeks of age). All animal experiments were approved by the Ethics Committee for Experimental Research, Jinzhou Medical University.

Biochemical indexmeasurements. Blood samples were collected from hearts prior to sacrifice. Fasting plasma glucose (FPG) and levels of triglyceride (TG), total cholesterol (TC), high-density lipoprotein (HD), low-density lipoprotein (LDL) and FFA were measured.

Hematoxylin \& eosin and Masson staining. Adipose tissue was collected from fresh sacrificed mice and fixed with $4 \%$ 
paraformaldehyde for $48 \mathrm{~h}$ before paraffin sections were obtained.H\&E and Masson staining were conducted according to the manufacturer's protocol (Wanleibio Co., Ltd., Shenyang, China).

Immunohistochemistry. Section, $5 \mu \mathrm{m}$ in thickness, were incubated with rabbit-anti-mouse collagen I (Beijing Biosynthesis Biotechnology Co., Ltd., Beijing, China) primary antibody overnight at $4^{\circ} \mathrm{C}$. Then slides were washed and incubated with 1:5,000 goat-anti-rabbit secondary antibody (Absci, Nanjing, China) for $4 \mathrm{~h}$. A DAB kit (OriGene Technologies, Inc., Beijing, China) was used to bind secondary antibody, according to the manufacturer's protocol.

Western blotting. Total proteins in adipose tissue were extracted with RIPA (with 1\% PMSF). BCA assay was used to detect protein concentrations in middle extracting solution. Targeting proteins were separated by SDS-PAGE, transferred to PVDF membranes and blocked with skim milk for $2 \mathrm{~h}$ at room temperature. Rabbit anti-mouse primary antibodies to collagen I (Wanleibio Co., Ltd.), MMP2 (Wanleibio Co., Ltd.), TIMP1 (Wanleibio Co., Ltd.), TLR2 (Beijing Biosynthesis Biotechnology Co., Ltd.), myd88 (Beijing Biosynthesis Biotechnology Co., Ltd.), TGF $\beta 1$ (Wanleibio Co., Ltd.), p38 MAPK (Bisson, Beijing, China), P-P38MAPK (Wanleibio Co., Ltd.), and $\beta$-actin (Absci) were used to bind targeting proteins. An ECL-sensitive kit (Wanleibio Co., Ltd.) was used to detect goat anti-rabbit secondary antibody binding.

RNA extraction and reverse transcription. Total RNA was extracted from adipose tissue using TRIzol reagent, then dissolved in RNase free water with RNase inhibitor. Prior to cDNA synthesis, RNA was monitored by Nandrop2000, and DEPC water was added to a concentration of $100 \mu \mathrm{g} / \mu \mathrm{l}$. Then DNA was removed in a mix $(10 \mu \mathrm{l})$ with RNA $(1 \mu \mathrm{l})$, $5 \mathrm{X}$ gDNA eraser buffer $(2 \mu \mathrm{l})$, gDNA eraser $(1 \mu \mathrm{l})$, and RNase free $\mathrm{dH} 2 \mathrm{O}(6 \mu \mathrm{l})$. cDNA was synthesized in a mix $(20 \mu \mathrm{l})$ with primer script RT enzyme mix $(1 \mu \mathrm{l})$, RT primer mix $(1 \mu \mathrm{l}), 5 \mathrm{X}$ primer script buffer $(4 \mu \mathrm{l})$, RNase free $\mathrm{dH} 2 \mathrm{O}(4 \mu \mathrm{l})$, and the mix $(10 \mu \mathrm{l})$ from the previous step. Reverse transcription was performed in $20-\mu 1$ reactions at $25^{\circ} \mathrm{C}$ for $10 \mathrm{~min}$, followed by $37^{\circ} \mathrm{C}$ for $15 \mathrm{~min}$, and finally denaturation at $85^{\circ} \mathrm{C}$ for $5 \mathrm{~min}$. cDNA was stored at $-80^{\circ} \mathrm{C}$ until further use. All experiments involving the PrimeScript ${ }^{\mathrm{TM}} \mathrm{RT}$ reagent kit with gDNA eraser (Takara Bio, Inc., Otsu, Japan) were performed according to the manufacturer's.

Polymerase chain reaction (PCR). Expression levels of IL-6 $m R N A$, TNF- $\alpha m R N A$ collagen I $\alpha 1 m R N A$, and collagen I $\alpha 2$ $m R N A$ were measured in a $20-\mu 1$ System with 2 XGreenStar Master mix $(10 \mu \mathrm{l})$, forward primer $(1 \mu \mathrm{l}, 10 \mathrm{pmol} / \mu \mathrm{l})$, reverse primer $(1 \mu \mathrm{l}, 10 \mathrm{pmol} / \mu \mathrm{l})$, DEPC water $(6 \mu \mathrm{l})$, and template DNA $(2 \mu \mathrm{l})$ obtained by reverse transcription. Primers were designed and synthesized by Sangon Biotech (Sangon Biotech Co., Ltd, Shanghai, China) (Table I). All reactions were performed in a $20-\mu 1$ volume for $30 \mathrm{sec}$ at $95^{\circ} \mathrm{C}$, followed by 45 cycles of $95^{\circ} \mathrm{C}$ for $5 \mathrm{sec}$, and $60^{\circ} \mathrm{C}$ for $34 \mathrm{sec}$. Relative quantification of gene expression was performed using the comparative $2^{-\Delta \Delta \mathrm{Ct}}$ method. GAPDH was used as a validated
Table I. Primers of collagen I $\alpha 1$, collagen I $\alpha 2$, IL6, TNF $\alpha$ and GAPDH.

Genes $\quad$ Primer sequences $\left(5^{\prime}-3^{\prime}\right)$

$\begin{array}{ll}\begin{array}{l}\text { Collagen I } \alpha 1 \\ \text { Forward } \\ \text { Reverse }\end{array} & \text { GACGGCTGAGTAGGGAACAC } \\ \text { Collagen I } \alpha 2 & \\ \text { Forward } & \text { ACCCCTGTGCCCTTTATCAC } \\ \text { Reverse } & \text { GGTTCTGTTGGTCCTGTTGG } \\ \text { IL6 } & \\ \text { Forward } & \text { ATGAAGTTCCTCTCTGCAAGAGACT } \\ \text { Reverse } & \text { CACTAGGTTTGCCGAGTAGATCTC } \\ \text { TNF } \alpha & \\ \text { Forward } & \text { TGTCTCAGCCTCTTCTCATT } \\ \text { Reverse } & \text { AGATGATCTGAGTGTGAGGG } \\ \text { GAPDH } & \\ \text { Forward } & \text { TTGTCAAGCTCATTTCCTGGTATG } \\ \text { Reverse } & \text { GGATAGGGCCTCTCTTGCTCA }\end{array}$

IL, interleukin; TNF- $\alpha$, tumor necrosis factor- $\alpha$.

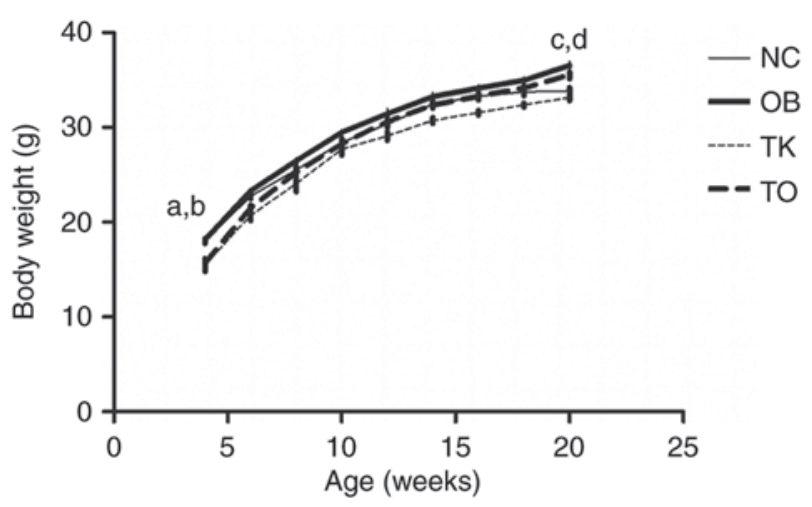

Figure 1. Body weights of mice. C57BL/6J mice and TLR2 gene knockout mice were weighed before the experiment. $\mathrm{C} 57 \mathrm{BL} / 6 \mathrm{~J}$ mice weighed more than TLR2 gene knockout mice [a, TK vs. $\mathrm{NC}(\mathrm{P}=0.045)$; $\mathrm{b}$, TO vs. OB $(\mathrm{P}=0.002)]$. At the end of the experiment, we measured an increased body weight in $\mathrm{OB}$ group vs. NC group $(\mathrm{P}=0.000)$ and TO group vs. TK group $(\mathrm{P}=0.000)$. Although not significant, mice were heaver in $\mathrm{OB}$ group than $\mathrm{TO}$ group $(\mathrm{P}=0.066)$.

reference gene. Real-time PCR experiments were performed according to the protocol provided by the manufacturer of the AccuPower 2xGreenStar qPCR Master Mix kit with gDNA eraser (Bioneer Corporation, Pangyo R\&D Center, Republic of Korea).

Statistical analysis. Data are presented as means \pm standard error (S.E.M.). Differences between groups were analyzed by one-way ANOVA with SPSS 20.0 (IBM Corp., Armonk, NY, USA). When appropriate, differences between groups were evaluated by LSD. Interaction effects were analyzed by analysis of variance of factorial design. $\mathrm{P}<0.05$ was considered to indicate a statistically significant difference. 


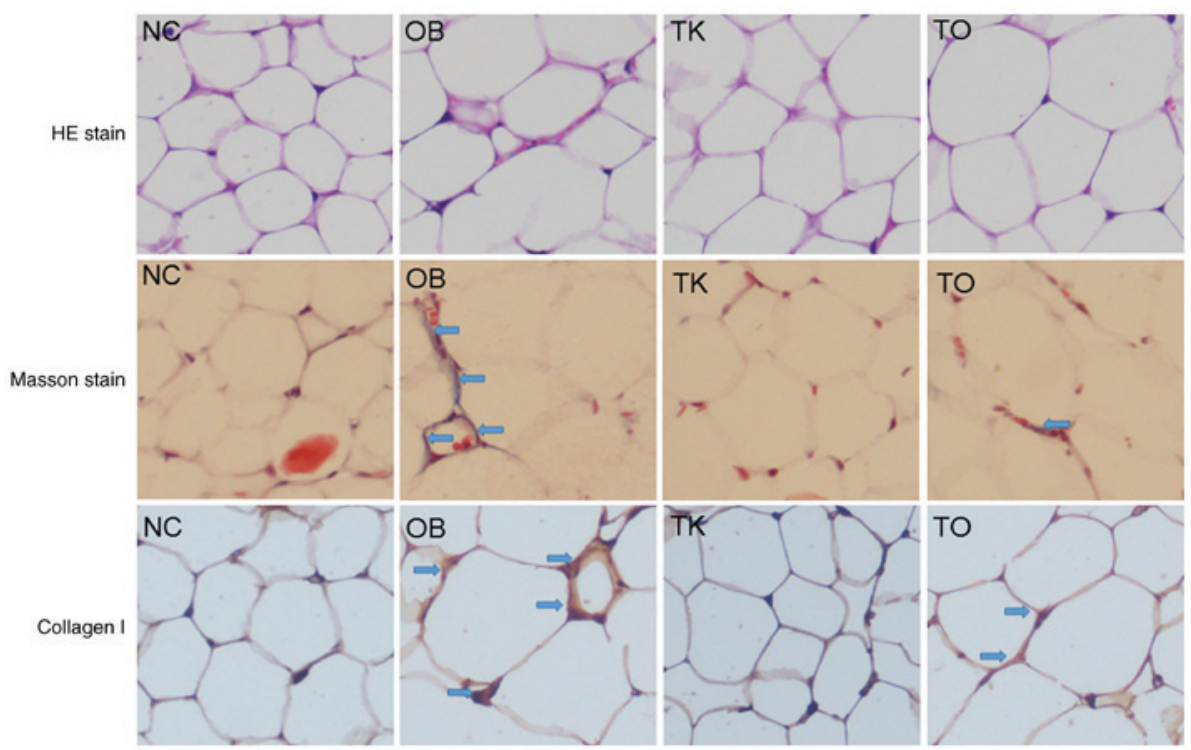

Figure 2. H\&E stain, Masson stain and collagen I immunohistochemistry. HE stain showed larger adipocytes in OB and TO compared with NC and TK mice. Blue arrows highlight total collagen staining. Collagen is significantly increased in the OB group compared with the TO group. Brown areas show collagen I.
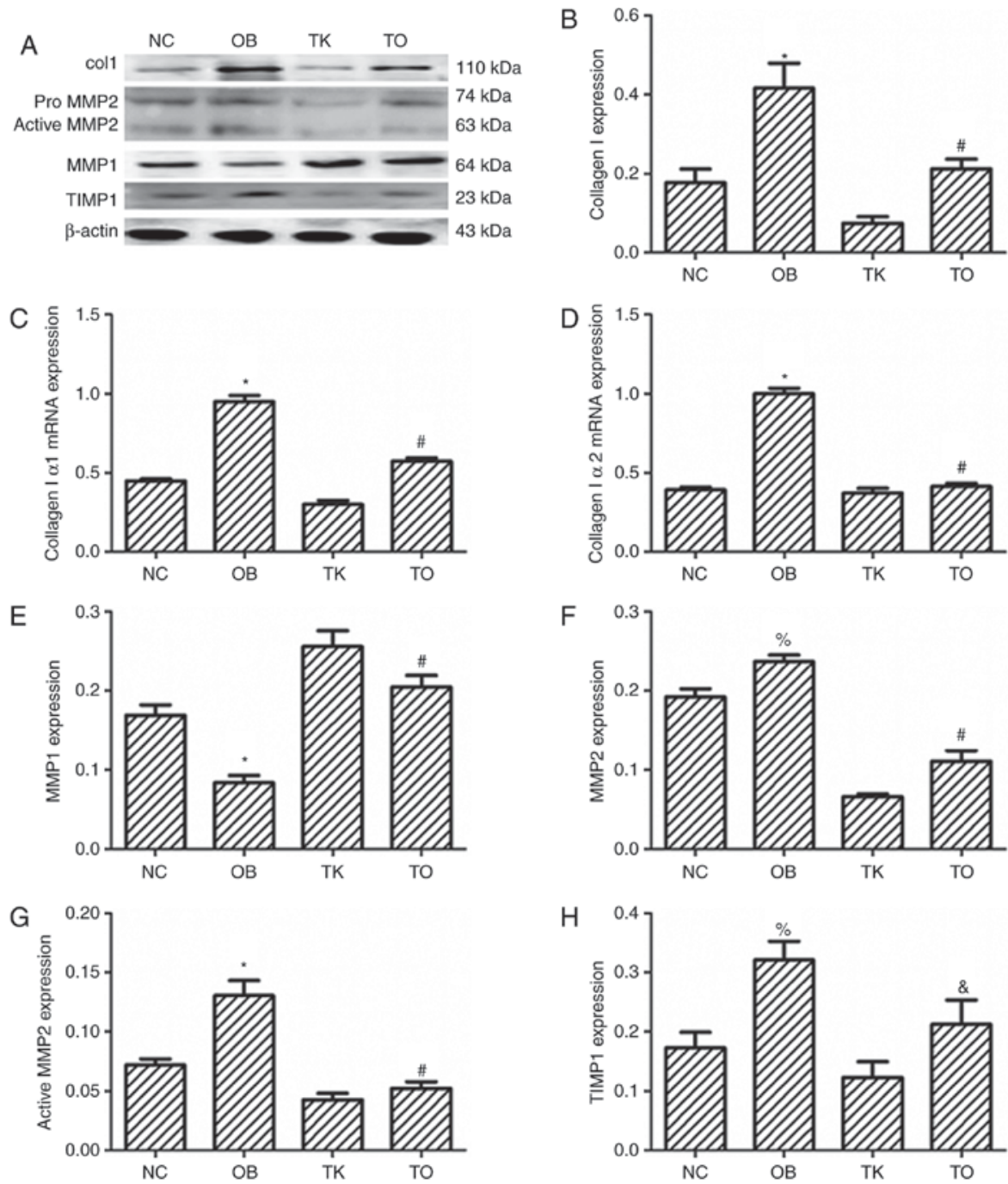

Figure 3. (A) Western blotting and RT-PCR to measure levels of (B) collagen I, (C) collagen I $\alpha 1 m R N A$, (D) collagen I $\alpha 2 m R N A$, (E) MMP1, (F) MMP2, (G) active MMP2, and (H) TIMP1. Increased collagen I, collagen I $\alpha 1$ mRNA, and collagen I $\alpha 2 m R N A$ in the OB group. Decreased collagen I, collagen I $\alpha 1$ $m R N A$, and collagen I $\alpha 2 m R N A$ in the TO group ( ${ }^{*} \mathrm{P}<0.01$ vs. $\left.\mathrm{NC} ;{ }^{*} \mathrm{P}<0.01 \mathrm{vs.} \mathrm{OB}\right)$. Increased levels of MMP2, active MMP2, and TIMP1 and decreased levels of MMP1 in the OB group. Decreased levels of MMP2, active MMP2, and TIMP1 and increased levels of MMP1 were observed in the TO group ("P $<0.01$, ${ }^{\%} \mathrm{P}<0.05$ vs. $\mathrm{NC}$; ${ }^{*} \mathrm{P}<0.01, \mathrm{P}<0.05$ vs. $\left.\mathrm{OB}\right)$. 
Table II. Levels of FPG, TC, TG, HDL, LDL and FFA in plasma of mice.

\begin{tabular}{lcrrr}
\hline Variable & NC & OB & TK & TO \\
\hline FPG (mmol/l) & $6.78 \pm 0.43$ & $9.79 \pm 0.32^{\mathrm{a}}$ & $6.37 \pm 0.46^{\mathrm{b}}$ & $6.88 \pm 0.33^{\mathrm{c}, \mathrm{e}}$ \\
TC (mmol/l) & $0.26 \pm 0.02$ & $0.37 \pm 0.03^{\mathrm{a}}$ & $0.08 \pm 0.01^{\mathrm{a}}$ & $0.12 \pm 0.02^{\mathrm{a}, \mathrm{c}, \mathrm{e}}$ \\
TG (mmol/l) & $2.64 \pm 0.06$ & $3.03 \pm 0.07^{\mathrm{a}}$ & $2.30 \pm 0.06^{\mathrm{b}}$ & $2.36 \pm 0.06^{\mathrm{a}, \mathrm{c}}$ \\
HDL (mmol/l) & $1.14 \pm 0.05$ & $1.05 \pm 0.02^{\mathrm{a}}$ & $0.98 \pm 0.03^{\mathrm{b}}$ & $0.94 \pm 0.02^{\mathrm{a}, \mathrm{c}, \mathrm{f}}$ \\
LDL (mmol/l) & $1.46 \pm 0.02$ & $1.65 \pm 0.07^{\mathrm{a}}$ & $1.19 \pm 0.03^{\mathrm{b}}$ & $1.2675+0.04^{\mathrm{a}, \mathrm{c}, \mathrm{e}}$ \\
FFA (mEq/l) & $670.40 \pm 22.10$ & $1124.89 \pm 36.37^{\mathrm{a}}$ & $552.85 \pm 23.08^{\mathrm{b}}$ & $563.73+26.37^{\mathrm{a}, \mathrm{c}}$
\end{tabular}

${ }^{\mathrm{a}} \mathrm{P}<0.01,{ }^{\mathrm{b}} \mathrm{P}<0.05$ vs. $\mathrm{NC} ;{ }^{\mathrm{c}} \mathrm{P}<0.01,{ }^{\mathrm{d}} \mathrm{P}<0.05$ vs. $\mathrm{OB} ;{ }^{\mathrm{e}} \mathrm{P}<0.01,{ }^{\mathrm{f}} \mathrm{P}<0.05$ vs. TK.
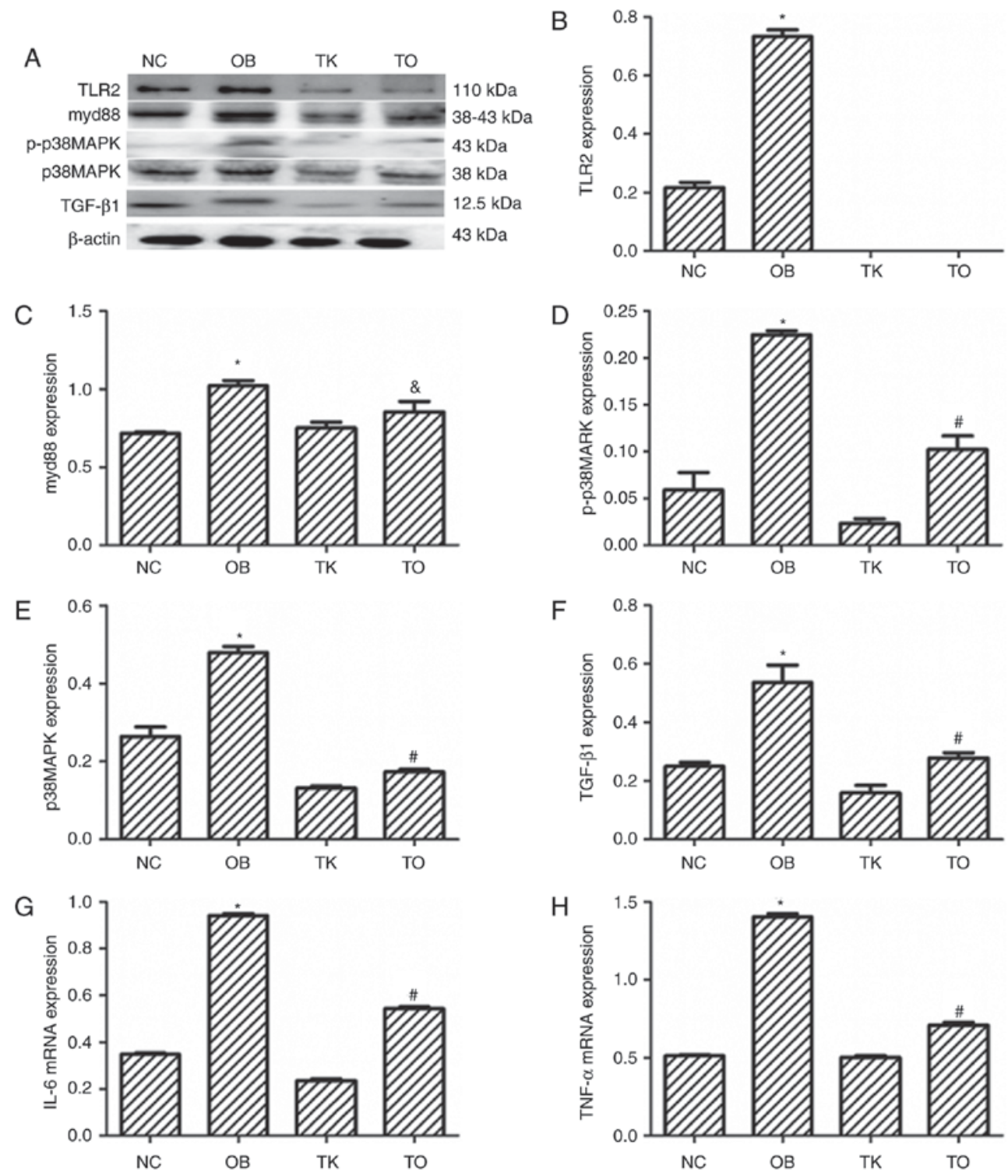

Figure 4. (A) Western blotting and RT-PCR to measure levels of (B) TLR2, (C) myd88, (D) p-p38MAPK, (E) p38 MAPK, (F) TGF- $\beta 1$, (G) IL6 mRNA and (H) TNF- $\alpha$ mRNA. Increased levels of TLR2, myd88, p-p38MAPK, p38MAPK, TGFß1, IL6 $m R N A$, and TNF $\alpha$ mRA levels in the NC group ("P<0.01 vs. NC). myd88, p-p38MAPK, p38MAPK, TGF 1 , IL6 $m R N A$, and TNFa $m R N A$ levels in the TO group ( ${ }^{\sharp} \mathrm{P}<0.01, \mathrm{P}<0.05$ vs. OB).

\section{Results}

At the start of the experiment, $\mathrm{C} 57 \mathrm{BL} / 6 \mathrm{~J}$ mice $(\mathrm{NC}$ and $\mathrm{OB}$ mice) were heavier than TLR2 gene knockout mice (TK and TO mice). However, there was no significant difference between the NC and OB as well as TK and TO mice groups. At 4 weeks, there was no significant difference among these 4 groups in weight. At 16 weeks, Weight was increased in the 
OB group as compared to the NC group, and decreased in the TO group compared to the OB group (Fig. 1).

Levels of TC, TG, LDL and FFA were higher in the OB group compared with the NC group. HLD level was lower in the OB group compared with the NC group. Levels of TC, TG, LDL, HDL and FFA were lower in the TO group compared with the OB group (Table II).

Masson stain revealed more collagen in adipose tissue in the OB group compared with the NC group. Levels of total collagen, collagen I, collagen I $\alpha 1 m R N A$, and collagen I $\alpha 2 m R N A$ increased in adipose tissue of OB compared with NC mice but decreased in TO compared with OB mice (Figs. 2 and 3).

Levels of active MMP2, MMP2, and TIMP1 were higher in OB compared with NC mice. Expression of MMP1 in adipose tissue was lower in OB compared with NC mice. Expression of active MMP2, MMP2, and TIMP1 was lower in TO compared with OB mice. Expression of MMP1 in adipose tissue was higher in TO compared with OB mice (Fig. 3).

Levels of TLR2, myd88, p38MAPK, p-p38MAPK and TGF- $\beta 1$ in adipose tissue were higher in OB compared with NC mice. Levels of TLR2, myd88, p38MAPK, p-p38MAPK, and TGF- $\beta 1$ in adipose tissue were lower in TO compared with OB mice (Fig. 4).

Expression levels of IL-6 $m R N A$ and TNF- $\alpha m R N A$ were up-regulated in adipose tissue of $\mathrm{OB}$ compared with $\mathrm{NC}$ mice, but down-regulated in TO compared with OB mice (Fig. 4).

\section{Discussion}

Our findings of increased total collagen and collagen I in adipose tissue of obese mice support previous reports (20). Levels of MMP2 and TIMP1, which regulate collagen I, were also increased in obese mice $(16,17)$. The increase in levels of MMP2 and TIMP1 was reported previously (8). Levels of MMP1, which also regulates collagen deposition, were observed to decrease in this study. The results presented here suggest that MMP1 and TIMP1 mediate the deposition of collagen I.

FFA activates TLR2, which in turn triggers the overexpression of proinflammatory factors (15). The adipose tissue of obese individuals is therefore characterized by chronic inflammation, which may be controlled by TLR2 (21). Such chronic inflammation increases the expression of MMPs and TIMPs (8). We believe that knocking out TLR2 reduced the expression of MMP1, TIMP1, and other inflammatory factors, reducing the deposition of collagen I in mice fed a high-fat diet. In this study, increased levels of myd88, p38 MAPK, p-p38 MAPK, IL-6, and TNF- $\alpha$ (inflammatory factors downstream of TLR2) were observed in the adipose tissue of OB compared with NC mice; levels of these factors were increased in the OB compared with the TO group. Compared with OB mice, TO mice had lower levels of collagen I and TIMP1 and higher levels of MMP1. TLR2 knockout appears to have increased the expression of MMP1 and decreased the expression of TIMP1. These factors likely reduced the level of collagen I deposition. These findings support the previous studies $(22,23)$. Genes knockout resulting in decreased levels fibrosis factors are reported to have decreased expression of inflammatory factors.

To further explore deposition of collagen I, collagen I $\alpha 1$ $m R N A$ and collagen I $\alpha 2 m R N A$ expression were measured in adipose tissue. OB mice showed up-regulation of collagen I $\alpha 1$ mRNA and collagen I $\alpha 2$ mRNA compared with NC mice. However, down-regulation of collagen I $\alpha 1$ mRNA and collagen I $\alpha 2$ mRNA were detected in TO mice compared with OB mice (Fig. 3). Statistical analysis revealed an interaction effect on collagen I $\alpha 1$ and collagen I $\alpha 2$ mRNA between high fat diet and TLR2 knocking out in adipose tissue of mice. These findings suggest that the transcription and translation of collagen I were affected by TLR 2 gene knockout and ingestion of a high-fat diet.

Higher expression of TGF $\beta 1$ was observed in OB compared with NC mice. TGF $\beta 1$ expression was lower in TO compared with $\mathrm{OB}$ mice. Elevated levels of cytokines such as TGF $\beta 1(13,21,24)$ trigger SMAD and non-SMAD signaling cascades that contribute to obesity (25-29) and fibrosis (30). Gene knockouts resulting in decreased levels of TGF $\beta 1$ are reported to have decreased expression of inflammatory factors $(22,23)$. TLR2 gene knockout appears to have had similar effects, resulting in fibrosis and the deposition of collagen $\mathrm{I}$ in adipose tissue.

In conclusion, the present results showed that TLR2 gene knockout may reduce collagen I expression in adipose tissue of mice with obesity. We hypothesize that this effect is mediated by a balance in pro -vs. anti-inflammatory factors and downstream MMP1, TIMP1, and TGF $\beta 1$.

\section{Acknowledgements}

The present study was supported by the Scientific Foundation for Doctoral Research (20131067) and Natural Scientific Foundation (201602308) at the Liaoning Science and Technology Administration Bureau. Professor Zheng and Professor Zhai in the Department of Brain and Spinal Cord injury in Liaoning province contributed substantially to this study.

\section{References}

1. Flegal KM, Carroll MD, Ogden CL and Curtin LR: Prevalence and trends in obesity among US adults, 1999-2008. JAMA 303: 235-241, 2010.

2. Flegal KM, Kruszon-Moran D, Carroll MD, Fryar CD and Ogden CL: Trends in obesity among adults in the United States, 2005 to 2014. JAMA 315: 2284-2291, 2016.

3. Ogden CL, Carroll MD, Lawman HG, Fryar CD, Kruszon-Moran D, Kit BK and Flegal KM: Trends in obesity prevalence among children and adolescents in the United States, 1988-1994 through 2013-2014. JAMA 315: 2292-2299, 2016.

4. Chan JC, Zhang Y and Ning G: Diabetes in China: A societal solution for a personal challenge. Lancet Diabetes Endocrinol 2: 969-979, 2014

5. Xu Y, Wang L, He J, Bi Y, Li M, Wang T, Wang L, Jiang Y, Dai M, Lu J, et al: Prevalence and control of diabetes in Chinese adults. JAMA 310: 948-959, 2013.

6. Huber J, Löffler M, Bilban M, Reimers M, Kadl A, Todoric J, Zeyda M, Geyeregger R, Schreiner M, Weichhart T, et al: Prevention of high-fat diet-induced adipose tissue remodeling in obese diabetic mice by $n-3$ polyunsaturated fatty acids. Int $\mathbf{J}$ Obes (Lond) 31: 1004-1013, 2007.

7. Khan T, Muise ES, Iyengar P, Wang ZV, Chandalia M, Abate N, Zhang BB, Bonaldo P, Chua S and Scherer PE: Metabolic dysregulation and adipose tissue fibrosis: Role of collagen VI. Mol Cell Biol 29: 1575-1591, 2009.

8. Lin, Chun TH and Kang L: Adipose extracellular matrix remodelling in obesity and insulin resistance. Biochem Pharmacol 119: 8-16, 2016.

9. Spencer M, Unal R, Zhu B, Rasouli N, McGehee RE Jr, Peterson CA and Kern PA: Adipose tissue extracellular matrix and vascular abnormalities in obesity and insulin resistance. J Clin Endocrinol Metab 96: E1990-E1998, 2011. 
10. Vila IK, Badin PM, Marques MA, Monbrun L, Lefort C, Mir L, Louche K, Bourlier V, Roussel B, Gui P, et al: Immune cell Toll-like receptor 4 mediates the development of obesity- and endotoxemia-associated adipose tissue fibrosis. Cell Rep 7: 1116-1129, 2014.

11. Dankel SN, Svärd J, Matthä S, Claussnitzer M, Klöting N, Glunk V, Fandalyuk Z, Grytten E, Solsvik MH, Nielsen HJ, et al: COL6A3 expression in adipocytes associates with insulin resistance and depends on PPAR $\gamma$ and adipocyte size. Obesity (Silver Spring) 22: 1807-1813, 2014.

12. Divoux A, Tordjman J, Lacasa D, Veyrie N, Hugol D, Aissat A, Basdevant A, Guerre-Millo M, Poitou C, Zucker JD, et al: Fibrosis in human adipose tissue: Composition, distribution, and link with lipid metabolism and fat mass loss. Diabetes 59: 2817-2825, 2010.

13. Spencer M, Yao-Borengasser A, Unal R, Rasouli N, Gurley CM, Zhu B, Peterson CA and Kern PA: Adipose tissue macrophages in insulin-resistant subjects are associated with collagen VI and fibrosis and demonstrate alternative activation. Am J Physiol Endocrinol Metab 299: E1016-E1027, 2010.

14. Barton GM and Medzhitov R: Toll-like receptor signaling pathways. Science 300: 1524-1525, 2003.

15. Kim S, Jin Y, Choi Y and Park T: Resveratrol exerts anti-obesity effects via mechanisms involving down-regulation of adipogenic and inflammatory processes in mice. Biochem Pharmacol 81: $1343-1351,2011$

16. Hopps E and Caimi G: Matrix metalloproteinases in metabolic syndrome. Eur J Intern Med 23: 99-104, 2012.

17. Hopps E and Caimi G: Matrix metalloproteases as a pharmacological target in cardiovascular diseases. Eur Rev Med Pharmacol Sci 19: 2583-2589, 2015.

18. Bourlier V, Sengenès C, Zakaroff-Girard A, Decaunes $P$, Wdziekonski B, Galitzky J, Villageois P, Esteve D, Chiotasso P, Dani $\mathrm{C}$ and Bouloumié A: TGFbeta family members are key mediators in the induction of myofibroblast phenotype of human adipose tissue progenitor cells by macrophages. PLoS One 7: e31274, 2012.

19. Henegar C, Tordjman J, Achard V, Lacasa D, Cremer I, Guerre-Millo M, Poitou C, Basdevant A, Stich V, Viguerie N, et al: Adipose tissue transcriptomic signature highlights the pathological relevance of extracellular matrix in human obesity. Genome Biol 9: R14, 2008.
20. Luo T, Nocon A, Fry J, Sherban A, Rui X, Jiang B, Xu XJ, Han J, Yan Y, Yang Q, et al: AMPK activation by metformin suppresses abnormal extracellular matrix remodeling in adipose tissue and ameliorates insulin resistance in obesity. Diabetes 65: 2295-2310, 2016.

21. Samad F, Yamamoto K, Pandey M and Loskutoff DJ: Elevated expression of transforming growth factor-beta in adipose tissue from obese mice. Mol Med 3: 37-48, 1997.

22. Adapala VJ, Ward M and Ajuwon KM: Adipose tissue biglycan as a potential anti-inflammatory target of sodium salicylate in mice fed a high fat diet. J Inflamm (Lond) 9: 15, 2012.

23. Nokhbehsaim M, Keser S, Nogueira AV, Jäger A, Jepsen S, Cirelli JA, Bourauel C, Eick S and Deschner J: Leptin effects on the regenerative capacity of human periodontal cells. Int J Endocrinol 2014: 180304, 2014.

24. Alessi MC, Bastelica D, Morange P, Berthet B, Leduc I, Verdier M, Geel $\mathrm{O}$ and Juhan-Vague I: Plasminogen activator inhibitor 1 , transforming growth factor-beta 1 and BMI are closely associated in human adipose tissue during morbid obesity. Diabetes 49: 1374-1380, 2000.

25. Johnson DL, Carnes D, Steffensen B and Cochran DL: Cellular effects of enamel matrix derivative are associated with different molecular weight fractions following separation by size-exclusion chromatography. J Periodontol 80: 648-656, 2009.

26. Okubo K, Kobayashi M, Takiguchi T, Takada T, Ohazama A, Okamatsu Y and Hasegawa K: Participation of endogenous IGF-I and TGF-beta 1 with enamel matrix derivative-stimulated cell growth in human periodontal ligament cells. J Periodontal Res 38: 1-9, 2003.

27. Prime SS, Pring M, Davies M and Paterson IC: TGF-beta signal transduction in oro-facial health and non-malignant disease (part I). Crit Rev Oral Biol Med 15: 324-336, 2004.

28. Sieber C, Kopf J, Hiepen C and Knaus P: Recent advances in BMP receptor signaling. Cytokine Growth Factor Rev 20: 343-355, 2009.

29. Suzuki S, Nagano T, Yamakoshi Y, Gomi K, Arai T, Fukae M, Katagiri T and Oida S: Enamel matrix derivative gel stimulates signal transduction of BMP and TGF-\{beta\}. J Dent Res 84: $510-514,2005$

30. Wynn TA: Cellular and molecular mechanisms of fibrosis. J Pathol 214: 199-210, 2008. 